\title{
Sometimes it is not as much about how as it is about why
}

\author{
Richard K. Freeman, MD, MBA
}

From the Department of Thoracic and Cardiovascular Surgery, St Vincent Hospital, Indianapolis, Ind. Disclosures: Author has nothing to disclose with regard to commercial support.

Received for publication Jan 27, 2017; accepted for publication Feb 1, 2017; available ahead of print Feb 22, 2017.

Address for reprints: Richard K. Freeman, MD, MBA, 8433 Harcourt Rd, Indianapolis, IN 46260 (E-mail:

Richard.Freeman@StVincent.org).

J Thorac Cardiovasc Surg 2017;153:1180-1

$0022-5223 / \$ 36.00$

Copyright (c) 2017 by The American Association for Thoracic Surgery

http://dx.doi.org/10.1016/j.jtcvs.2017.02.001

In this edition of the Journal, Demos and coauthors ${ }^{1}$ from Stanford University present a series of 18 adult patients who underwent unilateral thoracoscopic diaphragm plication. Their report concludes that the simplified technique of a single-suture plication resulted in an effective thoracoscopic diaphragm plication that produced significant improvements in pulmonary spirometry and dyspnea. Furthermore, Demos and coauthors ${ }^{1}$ demonstrated that these improvements were sustained for a relatively long period of follow-up.

Although Demos and coauthors ${ }^{1}$ are to be congratulated for these results, 2 other observations from this study deserve mention. The first is that, unlike many such reports related to diaphragm plication in the adult, Demos and coauthors ${ }^{1}$ used both objective (pulmonary spirometry) and validated subjective (a dyspnea scale) measures of each patient's response to diaphragm plication. The need for both types of evaluation is too often overlooked in a condition that, as Demos and coauthors ${ }^{1}$ point out, is relatively rare. They also used a standard approach to the indications for diaphragm plication. Both concepts are obviously important in supporting the conclusion that their technique is valid.

The second observation follows directly from the previous one. Although plication has been recognized as an appropriate treatment for unilateral paralysis or eventration of the diaphragm in children for many years, it is rarely performed in the adult. Despite the fact that unilateral diaphragm paralysis is relatively frequently diagnosed, few adult patients are referred for plication. This could be attributed either to a lack of familiarity with the possibility of surgical treatment by referring providers or to the absence of a surgeon willing to perform the procedure. The skepticism regarding diaphragm plication has also been exacerbated by the lack of standardized indications for surgery and the lack of objective or validated subjective data for improvement in many previous reports.

During the last decade, however, our group and others, with similar objective measures of respiratory function, have reported that surgical plication can significantly improve patients' symptoms and physiologic responses to unilateral diaphragm paralysis. ${ }^{2-4}$ Diaphragm plication has now been shown to be effective whether the plication



See Article page 1182.

See Editorial Commentary page 1189.

is performed through a thoracotomy, by thoracoscopy, robotically, or laparoscopically; the treatment effect is consistent (Table 6 in the article of Demos and coauthors ${ }^{1}$ ). As in this report of Demos and coauthors, ${ }^{1}$ the improvement has been shown to be sustained for extended follow-up periods.

So although Demos and coauthors ${ }^{1}$ are to be congratulated on a well-designed and well-executed investigation of a modified technique, the larger challenge for the community of thoracic surgeons is to become familiar with the indications and techniques of diaphragm plication. We as surgeons should be willing to engage these patients and their pulmonary physicians. Physicians with significant experience in the procedure should also report their experiences in an attempt to narrow the indications, contraindications, and timing of the procedure. Many of us will be pleasantly surprised by the difference that we can make in these patients' quality of life and respiratory function.

\section{References}

1. Demos DS, Berry MF, Backhus LM, Shrager JB. Video-assisted thoracoscopic diaphragm plication using a running suture technique is durable and effective. $J$ Thorac Cardiovasc Surg. 2017;153:1182-8.

2. Freeman RK, Van Woerkom JM, Vyverberg A, Ascioti AJ. Long term results of plication of the hemidiaphragm in adults with unilateral diaphragm paralysis. Ann Thorac Surg. 2009;88:1112-7. 
3. Groth SS, Rueth NM, Kast T, D'Cunha J, Kelly RF, Maddus MA, et al. Laparoscopic diaphragmatic plication for diaphragmatic paralysis and eventration: an objective evaluation of short-term and midterm results. J Thorac Cardiovasc Surg. 2010;139:1452-6.
4. Freeman RK, Wozniak TA, Fitzgerald EB. The functional and physiologic results of video-assisted thoracoscopic diaphragm plication in adult patients with unilateral diaphragm paralysis. Ann Thorac Surg. 2006;81:1853-7; discussion 1857 . 